\title{
Glasba kot povezovalni element predšolskih otrok z domačim okoljem
}

\author{
Majda Fras Leva \\ Samozaposlena v kulturi \\ majda.musica@gmail.com
}

\section{Bojan Kovačič \\ Univerza v Mariboru \\ bojan.kovacic@um.si}

\begin{abstract}
Prispevek preučuje glasbo kot povezovalni element predšolskih otrok z domačim okoljem. Za potrebe raziskave smo oblikovali avtorski koncept glasbenih uric, ki smo ga eno leto izvajali v treh vrtcih SV Slovenije. Preučevali smo, kako pogosto in katero obliko glasbene interakcije vzpostavljajo starši s svojimi otroki glede na vsebine, izvajane v vrtcu. Raziskovali smo zanimanje staršev za glasbene vsebine $v$ vrtcu, poznavanje ter oceno pomembnosti izvajanih vsebin. $V$ raziskavo je bilo vključenih 285 otrok obeh starostnih obdobij ter njihovi starši. Rezultati so pokazali, da sta najpogostejši glasbeni interakciji petje otroških pesmi in ples, starši pogosteje vzpostavljajo glasbeno interakcijo z mlajšimi otroki, s petjem se pogosteje povezujejo višje izobraženi starši. Ugotovitve kažejo na pomembno vlogo glasbe kot povezovalnega medija staršev in otrok z institucijami. Starši so se za izvajane glasbene vsebine zanimali ter jih ocenili kot pomembne.
\end{abstract}

Ključne besede: glasba na predšolski stopnji, glasbene dejavnosti, glasbena terapija, glasbena improvizacija, glasbena interakcija otrok - starš

\section{Uvod}

Glasba lahko predstavlja močno vez med institucionalnim in domačim oz. družinskim okoljem. Kot potencialna skupna točka varnosti prinaša številne prednosti ob prehodu iz domačega okolja v vrtec, iz ene starostne skupine $v$ drugo, kakor tudi s predšolske stopnje $v$ šolsko obdobje. Pri omenjenem prehajanju lahko starši z vzajemnim vključevanjem in poznavanjem vrtčevskih glasbenih vsebin z otrokom vzpostavijo skupno harmonično točko, ki nudi dodaten občutek varnosti. Kakovostne in konsistentne interakcije med otroki in odraslimi so soodvisne z varno obliko navezanosti v zgodnjem otroštvu. Takšno obliko navezanosti predšolskim otrokom omogoča občutljiva skrb staršev (Stern 2018; Cugmas 2020), ki je ključni dejavnik pri izogibanju razvojni psihopatologiji. Z upoštevanjem pomembnosti kakovostne interak- 
cije med otroki in starši lahko z glasbo, podobno kot Cugmasova $(2020,28)$ slikovito opiše raziskovalne izsledke $v$ teorijah navezanosti, dodamo »kamenček v mozaiku odkrivanja predstav navezanosti«. Ob kakovostni, zdravi navezanosti med otroki in starši je pomembno socialno vključevanje vseh otrok in staršev $v$ družbena dogajanja. $Z$ usmerjeno pozornostjo bi morali pristopati tudi do otrok s posebnimi potrebami. Prizadevamo si za kar največ »aktivnih in sodelovalnih oblik ter načinov dela z romskimi učenci in njihovimi starši, ki predstavljajo posebej ranljivo skupino oseb v družbeni skupnosti« (Topolovec in Schmidt 2015, 13). Tudi pri teh otrocih bi z ustreznimi glasbenimi pristopi lahko pripomogli k lažji premostitvi jezikovnih ovir ob vstopu v novo okolje ter $\mathrm{k}$ lažjemu povezovanju institucionalnega okolja $z$ domačim. Do vseh otrok, posebej še do otrok s posebnimi potrebami, želimo pristopati $z$ usmerjeno pozornostjo ter celostno. Takšen pristop do otrok predstavlja Peter Moss, profesor z londonske univerze, ki pripoznava pot pridobivanja kakovostne izobrazbe s pomočjo eksperimentalnih, inovativnih projektov že $\checkmark$ vrtcih ter namenja poudarek umetnosti, predvsem glasbi, ki je naravnana na celostni razvoj otrok (Kroflič 2011). Po navedbah Uletove (2015) imamo s pomočjo glasbe možnost omiliti kulturno diferenciacijo med družinami, kajti vpletenost staršev v izobraževalne procese pomeni obet za primerljive izhodiščne pogoje $v$ dobro otrok, kar velja tudi za pričujoče raziskovalno delo.

$\checkmark$ pričujočem prispevku izhajamo iz treh predpostavk, ki se nanašajo na interakcijo otroci - starši:

H1 Predpostavljamo, da je večina staršev s petjem, z igranjem na glasbila ali s plesom v pogosti interakciji s svojimi otroki.

$\mathrm{H}_{2}$ Predpostavljamo, da večina staršev pozna pesmice, ki se jih njihovi otroci učijo v vrtcu.

$\mathrm{H}_{3}$ Predpostavljamo, da otroci večini staršev pripovedujejo o glasbenih vsebinah $v$ vrtcu.

Namen raziskave je bil preučiti vpliv glasbe na pogostost interakcije otroci - starši, na oblike izvajanih glasbenih aktivnosti, na poznavanje pesmic iz vrtčevskega okolja in na stališča staršev o pomembnosti izvedenega eksperimentalnega projekta. Preverili smo statistično značilne razlike v pogostosti izvajanja glasbenih interakcij glede na izobrazbo staršev ter na starost otrok. Uporabili smo kvantitativni pristop pedagoškega raziskovanja, in sicer deskriptivno ter kavzalno neeksperimentalno metodo empiričnega pedagoškega raziskovanja. Podatke smo analizirali s statističnim paketom SPSS, verzija 21. Rezultate smo prikazali tabelarično. Uporabili smo absolutne (f) ter 
odstotne frekvence $(f \%)$. Za interpretacijo rezultatov smo izračunali odvisne zveze med spremenljivkami z uporabo preizkusa hi-kvadrat.

Iz konkretne populacije smo obravnavali dva neslučajnostna, namenska vzorca. Prvi vzorec je zajemal otroke, ki so se udeleževali Glasbenih uric v okviru opisanega pedagoškega eksperimenta. Za potrebe raziskave smo oblikovali vzorec 285 otrok. Otroci so bil razporejeni v 16 že poprej obstoječih vrtčevskih skupin, strokovna vodja vrtca je določila skupine za sodelovanje v programu Glasbenih uric. 135 otrok je bilo iz prvega starostnega obdobja (1-3 let) in 150 iz drugega (3-6 let), 159 (55,8\%) otrok je bilo moškega, 126 (44,2\%) pa ženskega spola. Drugi vzorec je zajemal starše. Struktura vzorca staršev glede na izobrazbo: 105 (36,9\%) staršev je s poklicno ali srednjo izobrazbo; 98 z višjo (34,4\%), visoko ali s 1. bolonjsko stopnjo; 82 (28,7\%) z univerzitetno ali 2. bolonjsko stopnjo, z znanstvenim magisterijem ali doktoratom, te starše smo zajeli v 3. stopnjo bolonjske izobrazbe.

Anketni vprašalnik je predstavljal temeljni raziskovalni instrument. Uporabili smo tristopenjsko lestvico, s katero smo merili pogostost izvajanih dejavnosti: 1. občasno (nekajkrat letno do nekajkrat mesečno), 2. tedensko, 3. vsakodnevno. S prvim sklopom vprašanj smo ugotavljali, kako pogosto starši z otroki pojejo otroške pesmi, igrajo na glasbila in plešejo. V drugem sklopu vprašanj nas je zanimalo, ali starši poslušajo/slišijo svoje otroke, preverjali smo tudi poznavanje pesmi, ki so se jih otroci učili v vrtcu. Poznavanje pesmic smo preverjali s tristopenjsko lestvico: 1. poznam, 2. delno poznam, 3. ne poznam. $S$ tretjim sklopom vprašanj smo od staršev pridobili ocene o pomembnosti vsebin izvajanih Glasbenih uric za njihove otroke. Ocene smo pridobili s pomočjo štiristopenjske lestvice Likertovega tipa z ocenami od 1 do 4 : 1. nepomembno, 2. manj pomembno, 3. pomembno, 4. posebej pomembno. Podatke smo zbirali s pomočjo anonimnih anketnih vprašalnikov od meseca maja do junija 2015. Staršem smo v vrtcu razdelili 336, vrnjenih smo dobili 285 izpolnjenih anketnih vprašalnikov.

Podrobneje nas je zanimal vpliv glasbe kot povezovalnega elementa na medsebojne odnose. Skladno s pretenzijo glasbenega povezovanja vrtčevskega okolja z domačim smo izvedli eksperimentalni projekt, ki je kot avtorski koncept poimenovan Glasbene urice z elementi glasbene terapije (Glasbene urice). Z njim smo z uporabo izbranih, v svetu poznanih elementov glasbene terapije sledili primerljivim konceptualnim rešitvam za slovenske vrtce, kakor predlaga Marjanovič Umekova (2014). Z metodo proste glasbene improvizacije smo vsak otrokov zvok, gib ali igranje na glasbilo uporabili za povezovanje z njim. Glasbene urice smo izvajali v treh vrtcih v SV Sloveniji, od avgusta 2014 do maja 2015, enkrat tedensko po 20-45 minut, odvisno od sta- 
rosti otrok. Koncept dela je temeljil, skladno z našo zasnovo ciljno izdelanega pilotskega projekta, ${ }^{1}$ na Orffovi glasbeni terapiji, katere utemeljiteljica je Gertrud Orff (1974).

Na vsaki urici sta bila prisotna dva strokovna delavca, vzgojitelj in pomočnik vzgojitelja, ki sta aktivno sodelovala pri izvajanju. $Z$ uporabo glasbenoterapevtskih elementov je bil vsak otrok slišan v skupini; vokalizirali so počutje, se gibali ob glasbi in prosto glasbeno improvizirali z igranjem na glasbila. $\mathrm{Na}$ uricah je bilo opaziti navdušenje in zanos, o katerem govorita Koširjeva in Habetova (2013), ta se z odraslih ob njihovima navdušenju in samouresničenosti prenaša na otroke. Izvajanje dejavnosti se je začenjalo $z$ vsebinami, $v$ katerih smo se uglasili na počutje otrok. $V$ pozdravni pesmi ${ }^{2}$ je bilo vključeno ime vsakega otroka, otroci so peli in/ali igrali na glasbila. Nato so plesali ob glasbi, med izvajanjem se je sonce (vzgojitelj) dotaknilo vsakega otroka, ga pobožalo in poklicalo po imenu. Medsebojna uglašenost se je izražala tudi z mehkimi plesnimi koraki ob pomirjujoči glasbi, igrani na pianino ali predvajani z zgoščenke. Primera poslušane glasbe: »Melodije štirih vetrov« (»Melodien der vier Winde«), delo Hansa Jürgena Hufeisena; »Glasba za panovo piščal: Violinska romanca št. 2 v F-duru, op. 50« (»Pänflote: Violinromanze Nr. 2, F-dur, op. 50«), delo Ludwiga van Beethovna. Nekateri otroci so skladbico nekaj časa poslušali sede, zatem so se začeli spontano gibati ob zvokih glasbe. V vsakokratnem izvajanju glasbenih dejavnosti so po začetnem uglaševanju $z$ glasbili prosto improvizirali na predstavljeno temo. Ena izmed uric je potekala na temo »Vsi smo velikani«. ${ }^{3}$ Otroci so bili razporejeni v tri skupine, v prvi so bili instrumentalisti, ki so spremljali korakanje velikanov, dež, sonce in premikanje dreves. Otroci druge skupine so bili v vlogi dreves, ki rastejo v savani, v vetru gibljejo drobne in velike veje ter pričakujejo velikane; otroci so premikali prste in telo. Tretja skupina otrok je bila $v$ vlogi velikanov, ki se sprehajajo med drevesi, kličejo dež, se pozdravljajo z drevesi in z njih obirajo sadeže. Stopali so z velikimi koraki v ritmu glasbe. Vsak otrok je ob menjavi skupin sodeloval v vsaki izmed skupin, vsi skupaj so peli »Pesem velikanov« ${ }^{4}$ Osrednje sporočilo dogajanja je bilo biti velikan v sodelovanju, poslušanju, prijateljstvu, prijaznosti, pospravljanju. Ker so otroci v glasbenih dejavnostih opazno uživali in z veseljem sodelovali, smo predpostavljali, da glas-

\footnotetext{
${ }^{1}$ Glasbene urice z elementi glasbene terapije.

${ }^{2}$ Uvodna situacijsko ustvarjena pesem s strani vodje projekta, peta ob spremljavi kitare. V glasbeni terapiji pozdravna pesem predstavlja običajno obliko uvodnega dela terapevtskega srečanja.

${ }^{3}$ Pesem iz avtorskega koncepta Glasbenih uric.

${ }^{4}$ Avtorsko delo izvajalke projekta.
} 
bene vsebine predstavljajo tudi staršem, o čemer smo prejemali povratne informacije.

\section{Glasbena terapija}

Otroci se izražajo verbalno in neverbalno, obe obliki se dopolnjujeta, ena drugo poudarita ali nadomestita (Paladin 2015). Področje, ki uspešno presega verbalne, komunikacijske in čustvene omejitve predšolskih otrok, je področje glasbene terapije. Implementacija njenih elementov v vzgojnovarstveno okolje (VVO) je dobrodošla za skladen fiziološki, psihološki, afektivni in duhovni razvoj (Wigram 2000; Oldfield in Flower 2008; Fallon idr. 2020). Svetovna organizacija za glasbeno terapijo (World Federation of Music Therapy b. I. ) glasbeno terapijo definira kot profesionalno uporabo glasbe in njenih elementov ter kot intervencijo v medicinskem, edukacijskem in vsakodnevnem okolju s posamezniki, z družinami ali s skupnostmi. Njen cilj je optimizacija kakovosti življenja in izboljšanje telesnega, socialnega, komunikacijskega, čustvenega, intelektualnega in duhovnega zdravja ter dobrega počutja. Glasbena terapija je izgradnja varnega prostora za srečevanja, kjer se lahko vsakdo počuti enakovrednega in sprejetega (Berger 2002; Jones 2006). Otroci se ob glasbi in zvoku srečujejo z mislimi in s čustvi na čuten ter izrazen način, če so za to nudeni ustrezni pogoji (Dana in loan 2013). Čustva so vkomponirana v izvajanje glasbenih dejavnosti z uporabo glasbene improvizacije v terapevtskem okvirju. Ob teh pogojih se lahko krepi čustveni spomin in modulirajo negativni čustveni zapisi v amigdali (Diaz Abrahan, Shifres in Justel 2020). Po tej poti se $z$ empatičnim, čutečim odnosom uglašujemo na potrebe otrok (Oldfield 2006). Posebej uglašeno in občutljivo je do otrok pristopala Gertrud Orff (1974), utemeljiteljica Orffove glasbene terapije, ki se je več desetletij ukvarjala $z$ otroki $z$ motnjami v razvoju ter opazovala vpliv glasbe in terapevtskega odnosa na njihov razvoj. Takšen podporni glasbenoterapevtski pristop do otrok je $v$ mnogih ustanovah uporabljen ne glede na bolezen ali prikrajšanost (Koelsch 2011; 2020; Wigram 2000; Mawby 2015; Fallon idr. 2020). V literaturi je zaznati poročanje o porastu uporabe glasbene terapije v svetu za zdrave posameznike (Hilliard 2007; Oldfield in Flower 2008 2008; Ilie in Rehana 2013; Koelsch 2020) ter vplivu glasbe na širši razvoj otrok s posebnimi potrebami v obdobju osnovnega šolanja (Čebulc 2009; Kopačin 2014).

\section{Prosta glasbena improvizacija}

Wigram $(2004,37)$ je glasbeno improvizacijo definiral kot »vsako kombinacijo zvokov ter zvoke, ki so ustvarjeni znotraj okvirja med začetkom in koncem«. 
Klinična glasbena improvizacija je terapevtska metoda, za katero je značilna »uporaba glasbene improvizacije $v$ zaupnem in podpornem okolju, vzpostavljenem s ciljem srečati se s potrebami klienta« (str. 40). Improvizacija, ki upošteva specifične glasbene parametre, je glasbena tehnika in ne terapevtska metoda. Prosto glasbeno improvizacijo ustvarimo iz katerega koli zvoka ali glasbila, s petjem, z gibanjem, upoštevaje trenutni potek in razvoj dogodkov. Preprostost in ustvarjalnost sta izhodiščni točki improvizacije, z intencijo oz. s pretenzijo »v varni povezanosti srečati idiosinkratske preference vsakogar« (str. 40). Z glasbenim jezikom v prosti glasbeni improvizaciji gradimo nove oblike komunikacije, zato je $v$ izvajanju izražen in sprejet širok spekter odzivov. Tudi moteče ali neželeno vedenje je ena izmed oblik komunikacije, kjer otrok na svojstven način izraža potrebe po sprejetosti. Za uspešno komunikacijo je te potrebe po mnenju Wigrama (2004) nujno prepoznati ter jih sprejeti, šele s sprejemanjem se bo otrok lahko poistovetil s skupino oz. sebe $v$ lastni notranjosti doživel kot sprejetega. Prosta glasbena improvizacija je »izvrstna eksperimentalna paradigma za preučevanje ustvarjalnosti v realnem času", saj vključuje otrokovo odločanje iz trenutka v trenutek (Adhikari idr. 2016, 772). Ne gre za zahtevo po novih dejavnostih, ampak za potrebo po svobodnem izražanju otrok. Ob preučevanju vpliva proste glasbene improvizacije na možganske aktivnosti je bilo s pomočjo elektroencefalografskih ${ }^{5}$ (EEG) signalov ugotovljeno, da je med potekom proste glasbene improvizacije oslabljen kognitivni nadzor, kar olajša ustvarjalnost in krepi sproščenost (Adhikari idr. 2016). Ob doživljanju sproščenosti ter izražanju ustvarjalnosti Oldfieldova (2006) improvizacijo opiše kot varen prostor za izražanje otrokovih stisk ter priložnost za krepitev komunikacije z okoljem. S pojmom improvizacija v našem delu dosledno mislimo na klinično ${ }^{6}$ glasbeno improvizacijo, poimenovali smo jo prosta glasbena improvizacija. Prosta je pričakovanj glasbenih ciljev, saj se osredotočamo na sprejemanje in svobodno izražanje otrok.

\section{Odzivi na glasbene interakcije}

Na glasbo se odzivajo vsa živa bitja, človeški plod v maternici že od 24. tedna nosečnosti (Johnson 2001). Petje pesmic in uspavank pripomore $\mathrm{h}$ krepitvi zgodnjega čustvenega odnosa med materjo in otrokom ter matere oz.

\footnotetext{
${ }^{5}$ »Metoda elektroencefalografije se $v$ medicini uporablja za beleženje zelo majhnih električnih impulzov, ki jih povzroča delovanje možganov.« (Smith 1994, 233) »Elektrode povežemo z napravo, ki meri možganske impulze v mikrovoltih.« (str. 234)

${ }^{6}$ Glasbena improvizacija, ki poteka v varnem okolju ob prisotnosti glasbenega terapevta.
} 
starše vabi v oblike intenzivnega glasbenega ukvarjanja z otroki (Hodges Wood 2008; Creighton, Atherton in Kitamura 2013). Ob poglobljeni čustveni povezanosti matere $z$ otrokom se z glasbenimi dejavnostmi krepi zmožnost pretvorbe negativnih čustvenih stanj v ugodna. Glasba lahko s svojimi komponentami ublaži stresna stanja (llie in Rehana 2013; Fallon idr. 2020). Poznan je vpliv glasbe, posameznih vokalov, na srčni utrip ter na večjo čustveno stabilnost staršev in otrok (Arnon idr. 2014). Vezni člen v glasbeni interakciji staršev z otroki je tudi gib, telesni izraz ob glasbi, ki otroka osvobaja vzorcev posnemanja (Wambach in Wambach 1999). Za lažje razumevanje v svojem delu gibalno-rajalno in plesno izražanje poimenujemo ples. Po navedbi B. Borota $(2015,15)$ je ples »dosežek, ki je spodbujen z glasbo, povezan z izražanjem doživetij ob glasbi«. Ples, petje, vokalizacija in igranje na glasbila so namenjeni izražanju čustev, osmišljajo in krepijo komunikacijo ter vzpostavljajo in poglabljajo socialne stike (Jacobsen, McKinney in Holck 2014; Simpson 2013; Countryman, Gabriel in Thompson 2015).

$V$ odzivanju na glasbo nam je na voljo lastna ustvarjalnost, spontano ustvarjanje pesmi, rim in ritmov (Baker in Wigram 2005). Glasbeni potek se po besedah Duha in Črčinovič Rozmanove (2007) razkriva kot logični proces, $\checkmark$ katerem so bolj kot posamezni deli pomembni odnosi in integracije. Za kakovostne odnose $v$ kontekstu interakcij otroci - starši je poslušanje ena najpomembnejših dejavnosti in potrebnih lastnosti (Fortuna in Nijs 2020). Pedagogika poslušanja »na najvišje mesto postavlja spoštovanje in odprtost do otroka« (Plut Pregelj 2012, 25). Izpostavljena je v pedagoškem konceptu Reggio Emilia (Kroflič 2011; Waters 2015). Usmerjena je v kvalitativne pridobitve za otroke znotraj organizacij šolskih sistemov ter v izgradnjo medsebojnih odnosov s starši (Waters 2015). Ob tako postavljenih izhodiščih se po besedah Jeznikove (2015) otrok lažje sreča z lastnim sebstvom, saj je že poprej sprejet $\mathrm{v}$ široko polje socialnih odnosov.

\section{Rezultati in interpretacija}

\section{Pogostost glasbene interakcije}

Preglednica 1 prikazuje pogostost glasbene interakcije otroci - starši. 173 $(60,7 \%)$ staršev se vsakodnevno ukvarja z otroki v pevski komunikaciji, 81 jih vsakodnevno izvaja ples $(28,4 \%)$ in $25(8,8 \%)$ jih vsakodnevno igra na glasbila. 102 starša $(35,8 \%)$ vsaj enkrat tedensko zaplešeta $z$ otroki. 183 staršev $(64,2 \%)$ ples z otrokom navaja kot pogosto glasbeno dejavnost, izvajajo jo tedensko (102 starša) ali vsakodnevno ( 81 staršev). 33,4 \% Oz. 95 staršev vsakodnevno ali tedensko uporablja igranje na glasbila kot način interakcije $z$ otrokom. Večina staršev je s petjem, z igranjem na glasbila ali s plesom v po- 
Preglednica 1 Števila $(f)$ in strukturni odstotki $(f \%)$ anketiranih staršev glede na pogostost izvajanja glasbene aktivnosti z otroki

\begin{tabular}{lrrrrrrrrrr}
\hline Pogostost & \multicolumn{2}{c}{ Petje } & & & \multicolumn{2}{c}{ Igranje } & & \multicolumn{3}{c}{ Ples } \\
\cline { 2 - 3 } & & $f$ & $f \%$ & & $f$ & $f \%$ & & $f$ & $f \%$ \\
\hline Občasno & 31 & 11,3 & & 190 & 66,6 & & 102 & 35,8 \\
Tedensko & 80 & 28,1 & & 70 & 24,6 & & 102 & 35,8 \\
Vsakodnevno & 173 & 60,7 & & 25 & 8,8 & & 81 & 28,4 \\
\hline Skupaj & 285 & 100,0 & & 285 & 100,0 & & 285 & 100,0 \\
\hline
\end{tabular}

Preglednica 2 Števila $(f)$ in strukturni odstotki $(f \%)$ anketiranih staršev v dejavnosti petja glede na starost otrok

\begin{tabular}{llrrrrrr}
\hline Pogostost & & \multicolumn{5}{c}{ Starost otrok v letih } & Skupaj \\
\cline { 2 - 7 } & & $1-2$ & $2-3$ & $3-4$ & $4-5$ & $5-6$ & \\
\hline Občasno & $f$ & 1 & 2 & 6 & 6 & 17 & 32 \\
& $f \%$ & 4,8 & 3,2 & 9,0 & 11,5 & 20,5 & 11,2 \\
\hline Tedensko & $f$ & 4 & 11 & 20 & 15 & 30 & 80 \\
& $f \%$ & 19 & 17,7 & 29,9 & 28,8 & 36,1 & 28,1 \\
\hline Vsakodnevno & $f$ & 16 & 49 & 41 & 31 & 36 & 173 \\
& $f \%$ & 76,2 & 79,0 & 61,2 & 59,2 & 43,4 & 60,7 \\
\hline Skupaj & $f$ & 21 & 62 & 67 & 52 & 83 & 285 \\
& $f \%$ & 100,0 & 100,0 & 100,0 & 100,0 & 100,0 & 100,0 \\
\hline
\end{tabular}

Opombe $\chi^{2}=24,321, p=0,002$.

gosti interakciji s svojimi otroki. Ples, petje in igranje na glasbila so dejavnosti za krepitev socialnih stikov (Jacobsen, McKinney in Holck 2014; Countryman, Gabriel in Thompson 2015), kjer so s posrednim vključevanjem udeleženi starši. Prosta glasbena improvizacija se s petjem, $\mathrm{z}$ igranjem na glasbila in $\mathrm{s}$ plesom usmerja v sodoživljanje z otroki (Schwartzberg in Silverman 2014), zato smo jo vtkali v vse oblike glasbenih dejavnosti.

\section{Petje}

Iz preglednice 2 razberemo, da je $43,4 \%$ pet- oz. šestletnikov vsakodnevno vključenih v pevsko aktivnost s svojimi starši, pri otrocih starostnega obdobja 1-2 let je delež vsakodnevno vključenih 76,2 \%. Ugotavljamo, da starši pogosteje pojejo $z$ mlajšimi otroki. Na podlagi $\chi^{2}$-preizkusa $\left(\chi^{2}=24,321, m=0,002\right)$ lahko potrdimo, da obstajajo statistično pomembne razlike $v$ pogostosti petja z otroki glede na njihovo starost. Vokaliziranje je otrokov prvobitni jezik, petje je pomembna vez uglašenosti ter krepitev interakcije otroci-odrasli (Oldfield 2006; Creighton, Atherton in Kitamura 2013). Po ugotovitvah raziskav 
Preglednica 3 Števila $(f)$ in strukturni odstotki $(f \%)$ anketiranih staršev v dejavnosti petja glede na izobrazbo staršev

\begin{tabular}{llrrrr}
\hline Pogostost & & \multicolumn{2}{c}{ Izobrazba staršev } & \multirow{2}{*}{ Skupaj } \\
\cline { 2 - 5 } & & $(1)$ & $(2)$ & $(3)$ & \\
\hline Občasno & $f$ & 19 & 10 & 3 & 32 \\
& $f \%$ & 18,1 & 10,1 & 3,7 & 11,2 \\
\hline Tedensko & $f$ & 27 & 29 & 24 & 80 \\
& $f \%$ & 25,7 & 29,3 & 29,6 & 28,1 \\
\hline Vsakodnevno & $f$ & 59 & 60 & 54 & 173 \\
& $f \%$ & 56,2 & 60,6 & 66,7 & 60,7 \\
\hline Skupaj & $f$ & 105 & 99 & 81 & 285 \\
& $f \%$ & 100,0 & 100,0 & 100,0 & 100,0 \\
\hline
\end{tabular}

Opombe (1) Osnovna do srednja, (2) visoka, višja, bolonjska I, (3) bolonjska II, III. $\chi^{2}=9,764, p$ $=0,045$.

(llie in Rehana 2013; Fallon idr. 2020) je petje pomembna interakcija za poglobljeno čustveno navezanost med otrokom in odraslim.

Kot razberemo iz preglednice 3 , obstajajo statistično pomembne razlike $\mathrm{v}$ pogostosti pevske interakcije $z$ otroki glede na izobrazbo staršev $\left(\chi^{2}=9,764\right.$, $p=0,045)$. Le trije starši iz skupine $z$ najvišjo izobrazbo se s pevsko interakcijo $z$ otroki povezujejo občasno, kar je gotovo spodbuden podatek. Pri večini vzorca prevladuje vsakodnevna interakcija. $Z$ izvajanjem, s poslušanjem ali z ustvarjanjem pesmi se krepita potrpežljivost in sprejemanje tudi pri starših, kar vodi do pomiritve otrok in staršev (Creighton, Atherton in Kitamura 2013). Koristi vidimo tudi drugje. $V$ testiranju inteligentnosti, ki ga je $v$ raziskavi izvedla Kopačinova $(2014,91)$, je bilo ugotovljeno, da »najvišje rezultate dosegajo otroci, ki s svojimi starši redno pojejo, obiskujejo glasbene prireditve, starši jih spodbujajo h glasbenim aktivnostim«.

\section{Igranje na glasbila}

$\checkmark$ preglednici 4 so prikazani rezultati o pogostosti igranja na glasbila glede na starost otrok. Razlika v pogostosti interakcije med otroki in starši v igranju na glasbila je na ravni statistične pomembnosti $(p=0,001)$, starši pogosteje igrajo na glasbila z mlajšimi otroki. Vsakodnevno na glasbila igra $14,3 \%$ staršev 1-2-letnih otrok, 12,9\% staršev 2-3-letnih otrok, 7,5\% staršev 3-4-letnih otrok, $7,7 \%$ staršev 4-5-letnih otrok ter $6 \%$ staršev 5-6-letnih otrok. Skupni rezultati našega vzorca kažejo, da interakcija v igranju na glasbila najpogosteje poteka občasno. Spodbujanje tovrstnih aktivnosti med otroki in starši je lahko tudi v domeni VVO. 
Preglednica 4 Števila $(f)$ in strukturni odstotki $(f \%)$ anketiranih staršev v igranju na glasbila glede na starost otrok

\begin{tabular}{llrrrrrr}
\hline Pogostost & & \multicolumn{4}{c}{ Starost otrok v letih } & \multirow{2}{*}{ Skupaj } \\
\cline { 2 - 7 } & & $1-2$ & $2-3$ & $3-4$ & $4-5$ & $5-6$ & \\
\hline Občasno & $f$ & 12 & 32 & 54 & 32 & 60 & 190 \\
& $f \%$ & 57,1 & 51,6 & 32,8 & 80,6 & 45,3 & 66,7 \\
\hline Tedensko & $f$ & 6 & 22 & 8 & 16 & 18 & 70 \\
& $f \%$ & 28,6 & 35,3 & 11,9 & 30,8 & 21,7 & 24,6 \\
\hline Vsakodnevno & $f$ & 3 & 8 & 5 & 4 & 5 & 25 \\
& $f \%$ & 14,3 & 12,9 & 7,5 & 7,7 & 6,0 & 8,8 \\
\hline Skupaj & $f$ & 21 & 62 & 67 & 52 & 83 & 285 \\
& $f \%$ & 100,0 & 100,0 & 100,0 & 100,0 & 100,0 & 100,0 \\
\hline
\end{tabular}

Opombe $\chi^{2}=26,304, p=0,001$.

Preglednica 5 Števila $(f)$ in strukturni odstotki $(f \%)$ anketiranih staršev v igranju na glasbila glede na izobrazbo staršev

\begin{tabular}{llrrrr}
\hline Pogostost & & \multicolumn{3}{c}{ Izobrazba staršev } & Skupaj \\
\cline { 2 - 5 } & & $(1)$ & $(2)$ & $(3)$ & \\
\hline Občasno & $f$ & 73 & 68 & 49 & 190 \\
& $f \%$ & 69,6 & 68,7 & 60,5 & 66,7 \\
\hline Tedensko & $f$ & 21 & 21 & 28 & 70 \\
& $f \%$ & 20,0 & 21,2 & 34,6 & 24,6 \\
\hline Vsakodnevno & $f$ & 11 & 10 & 4 & 25 \\
& $f \%$ & 10,5 & 10,01 & 4,9 & 8,8 \\
\hline Skupaj & $f$ & 105 & 99 & 81 & 285 \\
& $f \%$ & 100,0 & 100,0 & 100,0 & 100,0 \\
\hline
\end{tabular}

Opombe (1) Osnovna do srednja, (2) visoka, višja, bolonjska I, (3) bolonjska II, III. $\chi^{2}=20,332$, $p=0,002$.

V preglednici 5 so prikazani rezultati $\chi^{2}$-testa, ki dokazujejo, da je razlika glede na izobrazbo staršev $\mathrm{v}$ pogostosti igranja na glasbila $\mathrm{z}$ otroki statistično pomembna $(p=0,002)$. Najpogosteje z otroki vsakodnevno igrajo starši z osnovno in s srednjo izobrazbo (10,5\%). 10,01 \% je staršev z visoko in višjo izobrazbo ter s I. bolonjsko stopnjo, 4,9\% je staršev z izobrazbo II. in III. bolonjske stopnje, vsi navedeni so v vsakodnevni interakciji z otroki pri igranju na glasbila. Igranje na glasbila se je $v$ našem eksperimentalnem projektu najbolj približalo konstruktu proste glasbene improvizacije, ki jo Oldfieldova (2006) opisuje kot varen prostor za izražanje otrokovih stisk ter priložnost za krepitev komunikacije z okoljem. $\vee$ raziskavi ugotavljamo, da je igranje na glasbila dejavnost, ki nudi priložnost za nove glasbene interakcije otroci - starši. Po 
Preglednica 6 Števila $(f)$ in strukturni odstotki $(f \%)$ anketiranih staršev v pogostosti izvajanja plesa glede na starost otrok

\begin{tabular}{llrrrrrr}
\hline Pogostost & & \multicolumn{4}{c}{ Starost otrok v letih } & \multirow{2}{*}{ Skupaj } \\
\cline { 2 - 7 } & & $1-2$ & $2-3$ & $3-4$ & $4-5$ & $5-6$ & \\
\hline Občasno & $f$ & 3 & 14 & 22 & 21 & 42 & 102 \\
& $f \%$ & 10,3 & 22,6 & 32,9 & 10,4 & 50,6 & 9,8 \\
\hline Tedensko & $f$ & 8 & 19 & 33 & 15 & 27 & 102 \\
& $f \%$ & 38,1 & 30,6 & 19,3 & 28,8 & 32,5 & 35,8 \\
\hline Vsakodnevno & $f$ & 10 & 29 & 12 & 16 & 14 & 81 \\
& $f \%$ & 47,6 & 46,8 & 17,9 & 30,8 & 16,9 & 28,4 \\
\hline Skupaj & $f$ & 21 & 62 & 67 & 52 & 83 & 285 \\
& $f \%$ & 100,0 & 100,0 & 100,0 & 100,0 & 100,0 & 100,0 \\
\hline
\end{tabular}

Opombe $\chi^{2}=41,891, p=0,000$.

navedbi B. Borota $(2015,36)$ je »ritem način za uvajanje $v$ branje in pisanje glasbe«, tukaj govorimo o enem izmed načinov izvajanja in ustvarjanja ritmičnih vsebin.

\section{Ples}

Iz preglednice 6 razberemo, kako pogosto starši plešejo s svojimi otroki. Razlika v pogostosti plesa glede na starost otrok je na ravni statistične pomembnosti, rezultat $\chi^{2}$-preizkusa je $p=0,000$. Po ugotovitvah naše raziskave je ples najbolj priljubljena dejavnost za starše z najmlajšimi otroki, najopazneje se intenzivna plesna interakcija zmanjša v starosti 5-6 let, saj le 16,9 \% staršev $z$ otroki v tem starostnem obdobju vzpostavlja vsakodnevno plesno interakcijo. Večina staršev $(50,6 \%)$ otrok v starostnem obdobju 5-6 let je z njimi v občasni plesni interakciji, kar pomeni, od nekajkrat letno do nekajkrat mesečno. Vsakodnevno plesno interakcijo z otroki v starosti 1-2 let izvaja 47,6 \% staršev, v starostnem obdobju 2-3 leta pa 46,8. Spodbuden je podatek, da so v starostni skupini otrok 1-2 let samo trije starši, ki le občasno vzpostavljajo plesno interakcijo z otroki.

$\checkmark$ preglednici 7 je prikazana pogostost plesne interakcije otroci - starši glede na izobrazbo staršev. Izid $\chi^{2}$-preizkusa $(p=0,903)$ nam pove, da razlika $v$ pogostosti izvajanja plesa glede na izobrazbo staršev ni na ravni statistične pomembnosti. Vsakodnevno se $z$ otroki v plesni interakciji povezuje $26(24,8 \%)$ staršev z osnovno do srednjo izobrazbo, 31 (31,3\%) staršev z visoko in višjo šolo ter s prvo bolonjsko stopnjo izobrazbe, 24 (29,6\%) staršev pa z drugo in s tretjo bolonjsko stopnjo izobrazbe. Po mnenju Orffove (1974) je ples oz. gibanje z izkušnjo prostora izrazna raven otroka. Tudi s pomočjo 
Preglednica 7 Števila $(f)$ in strukturni odstotki $(f \%)$ anketiranih staršev v izvajanju plesa glede na izobrazbo staršev

\begin{tabular}{llrrrr}
\hline Pogostost & & \multicolumn{3}{c}{ Izobrazba staršev } & Skupaj \\
\cline { 2 - 5 } & & $(1)$ & $(2)$ & $(3)$ & \\
\hline Občasno & $f$ & 39 & 36 & 27 & 102 \\
& $f \%$ & 37,2 & 36,4 & 33,4 & 35,8 \\
\hline Tedensko & $f$ & 40 & 32 & 30 & 102 \\
& $f \%$ & 38,1 & 32,3 & 37,0 & 35,8 \\
\hline Vsakodnevno & $f$ & 26 & 31 & 24 & 81 \\
& $f \%$ & 24,8 & 31,3 & 29,6 & 28,4 \\
\hline Skupaj & $f$ & 285 & 105 & 81 & 285 \\
& $f \%$ & 100,0 & 100,0 & 100,0 & 100,0 \\
\hline
\end{tabular}

Opombe (1) Osnovna do srednja, (2) visoka, višja, bolonjska I., (3) bolonjska II., III. $\chi^{2}=2,176, p$ $=0,903$.

plesa otroci dobijo priložnost za izražanje čustev in počutja (Dana in loan 2013), zato so spodbudni podatki o pogosti plesni interakciji med otroki in starši ne glede na stopnjo izobrazbe.

Rezultati, predstavljeni v preglednicah $1-7$, potrjujejo predpostavko $\left(\mathrm{H}_{1}\right)$, da je večina staršev $s$ petjem, $z$ igranjem na glasbila ali s plesom $v$ pogosti interakciji s svojimi otroki.

\section{Poznavanje in ocena glasbenih vsebin v vrtcu s strani staršev}

Iz preglednice 8 razberemo, da 150 staršev $(52,6 \%)$ pozna in 78 staršev $(27,4 \%)$ delno pozna pesmice, ki so se jih njihovi otroci naučili v vrtcu, skupaj torej 228 (80\%). Med izvajanjem projekta Glasbene urice smo spremljali zanimanje staršev ter opis odzivov njihovih otrok $v$ domačem okolju. Starši so pesmi v obliki notnega gradiva z opisom izvajanja lahko prejeli v vrtcu ali jih spremljali na oglasni deski. Prav tako so bili z opisi ter z videoposnetki izvajanih glasbenih vsebin seznanjeni na roditeljskih sestankih ter na pogovornih urah. $V$ vrtcu so bile za starše organizirane številne prireditve, na katerih so sodelovali tudi otroci, vključeni v Glasbene urice. Predpostavka $\left(\mathrm{H}_{2}\right)$, da večina staršev pozna pesmice, ki se jih njihovi otroci učijo v vrtcu, je bila upravičena. Poznavanje vrtčevskih glasbenih vsebin s strani staršev krepi glasbeno interakcijo v domačem okolju.

Rezultati v preglednici 9 kažejo, da $103(36,1 \%)$ otroci redno in $89(31,2 \%)$ otrok občasno staršem pripoveduje o glasbenih vsebinah v vrtcu. Večini staršev otroci pripovedujejo o glasbenih vsebinah v vrtcu, kar pomeni, da je bila predpostavka $\left(\mathrm{H}_{3}\right)$ upravičena. Menimo, da otroci v družinsko okolje spon- 
Preglednica 8 Števila $(f)$ in strukturni odstotki $(f \%)$ anketiranih staršev glede poznavanja pesmic v vrtcu

\begin{tabular}{lrr}
\hline Poznavanje pesmic & $f$ & $f \%$ \\
\hline Ne poznam & 57 & 20,0 \\
Delno poznam & 78 & 27,4 \\
Poznam & 150 & 52,6 \\
Skupaj & 285 & 100,0 \\
\hline
\end{tabular}

Preglednica 9 Števila $(f)$ in strukturni odstotki $(f \%)$ anketiranih staršev glede na pripovedovanje otrok o glasbenih vsebinah $v$ vrtcu

\begin{tabular}{lrr}
\hline Pripovedovanje otrok & $f$ & $f \%$ \\
\hline Ne vem & 8 & 2,8 \\
Ne opazim & 85 & 29,8 \\
Včasih opazim & 89 & 31,2 \\
Redno opažam & 103 & 36,1 \\
\hline Skupaj & 285 & 100,0 \\
\hline
\end{tabular}

Preglednica 10 Ocena staršev o pomembnosti Glasbenih uric za njihove otroke

\begin{tabular}{rrrrr}
\hline$f$ & Najnižja ocena & Najvišja ocena & Povprečje & Standardni odklon \\
\hline 285 & 1,00 & 4,00 & 3,515 & 0,554 \\
\hline
\end{tabular}

tano integrirajo praktične glasbene izkušnje iz vrtca. 29,8\% oziroma 85 je staršev, ki ne opazijo, in 2,8\% oziroma 8 staršev ne ve, ali jim otroci pripovedujejo o glasbenih vsebinah v vrtcu. Domnevamo, da teh skupno 32,6\% zajema tudi starše, katerih otroci še ne zmorejo razumljivo govoriti zaradi nerazvitega besednjaka. Starši s poslušanjem otrok posredno spremljajo glasbene vsebine $v$ vrtcu ter tako krepijo interakcijo $z$ njimi. S poslušanjem in slišanjem otrok smo v institucijah usmerjeni v kvalitativne pridobitve za otroke ter v izgradnjo njihovih medsebojnih odnosov s starši (Kroflič 2011).

Iz preglednice 10 je razvidna povprečna ocena staršev o pomembnosti Glasbenih uric za njihove otroke. Starši so oceno pomembnosti podali glede na štiristopenjsko lestvico ( $1=$ nepomembno, $2=$ manj pomembno, $3=$ pomembno, 4 = posebej pomembno). Pomembnost izvajanih dejavnosti so ocenili s povprečno oceno 3,51 , kar je med ocenama pomembno in posebej pomembno. Spodbudno je, da se starši zanimajo za glasbene vsebine $v$ okolju VVO, kar za otroke pomeni dodatno vez ob vsakodnevnih prehodih iz domačega $v$ vrtčevsko okolje.

\section{Sklep}

S pričujočo raziskavo smo ugotovili, da je glasba lahko povezovalni element med predšolskimi otroci in domačim okoljem. Z glasbenimi dejavnostmi, ki so bile izvajane $v$ vrtcu, moremo posredno vplivati na pogostost glasbene interakcije otroci - starši (petje, igranje na glasbila in ples) $v$ domačem okolju. Potrdili smo, da je petje najpogostejša oblika glasbene komunikacije 
med otroki in starši. Manj pogosto izvajani glasbeni interakciji med njimi sta ples ter igranje na glasbila. Vpliv izobrazbe na pogostost petja je statistično pomemben; višje izobraženi starši z otroki pogosteje pojejo, manj izobraženi starši z njimi pogosteje igrajo na glasbila. Statistično pomembne razlike glede vpliva izobrazbe na izvajanje plesa z otroki nismo potrdili. Starši so pomembnost Glasbenih uric ocenili ugodno, povprečna ocena na štiristopenjski lestvici je bila 3,51. Ugotovili smo, da so se za vrtčevske glasbene vsebine zanimali, da $v$ večini ( $80 \%$ ) poznajo ali delno poznajo pesmice, ki smo jih z otroki izvajali na Glasbenih uricah.

Rezultati raziskave so pokazali, da glasba pomembno vpliva na interakcijo med otroki in starši ter tako povezuje vrtčevsko okolje $z$ domačim. Naša raziskava je skladna z ugotovitvami nekaterih drugih raziskav o vplivu glasbe na interakcijo otroci - starši (Oldfield 2006; Hodges Wood 2008; Creighton, Atherton in Kitamura 2013; Simpson 2013; Jacobsen, McKinney in Holck 2014; Countryman, Gabriel in Thompson 2015; Waters 2015). Glasba je pomembna vez za izgradnjo socialnega kapitala tudi v kontekstu preučevanih Glasbenih uric z elementi glasbene terapije. Koristno je integrirati posamezne elemente glasbene terapije v izvajanje pedagoških eksperimentov. Čeprav naša raziskava ni bila usmerjena v pridobivanje povratnih informacij s strani strokovnih delavcev, smo od njih prejeli pobude za stalno tovrstno dejavnost. Strokovni delavci so podali ugodne odzive glede vplivov izvajanih dejavnosti na lastno počutje in umirjanje kakor tudi na ustvarjalnost ter navdušenje otrok med potekom opisanega glasbenega projekta. Izbrani elementi glasbene terapije so pomembno prispevali h gradnji varnega prostora in čutečega, navdušujočega odnosa z otroki, zato smo upravičeno sklepali, da so otroci del navdušenja v obliki glasbene interakcije s starši iz vrtca prenesli tudi v domače okolje.

Pričujoča raziskava prispeva k prepoznavanju vloge glasbe kot povezovalnega elementa med družinskim in institucionalnim okoljem, ki lahko otroku nudi varno in poznano točko tudi ob prehodu v osnovno šolo. Glasbene urice $z$ elementi glasbene terapije so starši podprli, kar lahko pripomore $k$ uspešnejšemu prenosu glasbenoterapevtskih elementov v potek dela VVO. Starši so za otroke stalen in zanesljiv dejavnik ob prehodih iz domačega v vrtčevsko okolje. Ključna povezovalna točka obeh okolij je glasba, ki predstavlja vez za izgradnjo socialnega kapitala, hkrati tudi kulturnega bogastva. S pomočjo vpetosti v glasbene aktivnosti bodo otroci lažje ohranjali in krepili občutek pripadnosti tudi novim skupnostim, ki jim bodo med izobraževanjem pripadali oz. vanje vstopali ob pomembnih življenjskih prehodih. Pričujoča raziskava lahko predstavlja korak h kvalitativnim pridobitvam za otroke znotraj 
institucij, s katerimi v povezavi z domačim okoljem udejanjamo konsistentno skrb zanje.

\section{Literatura}

Adhikari, B. M., M. Norgaard, K. M. Quinn, J. Ampudia, J. Squirek in M. Dhamala. 2016. »The Brain Network Underpinning Novel Melody Creation." Brain Connectivity 6 (10): 772-785.

Arnon, S., C. Diamant, S. Bauer, R. Regev, G. Sirota in I. Litmanovitz. 2014. »Maternal Singing During Kangaroo Care Led to Avtomatic Stability in Preterm Infants and Reduced Maternal Anxiety.«Acta Paediatrica 103 (10): 1039-1044.

Baker, F., in T. Wigram, eds. 2005. Songwriting. London: Jessica Kingsley.

Berger, D. S. 2002. Music Therapy, Sensory Integration and the Autistic Child. London: Jessica Kingsley.

Borota, B. 2015. Glasbene dejavnosti in vsebine. Koper: Annales.

Countryman, J., M. Gabriel in K. Thompson. 2015. „Children Spontaneous Vocalisations During Play: Aesthetic Dimensions. «Music Education Research 18 (1): 1-19.

Creighton, A., M. Atherton in C. Kitamura. 2013. "Singing Playsongs and Lullabies: Investigating the Subjective Contributions to Maternal Attachment Constructs." The Australian Journal of Music Therapy 24:17-44.

Cugmas, Z. 2020. Večkratna navezanost. Ljubljana: i2.

Čebulc, M. 2009. »Glasbeno udejstvovanje ter koncentracija in dosežki učencev.« Doktorska disertacija, Univerza v Ljubljani.

Dana, R. M., in S. loan. 2013. »Developing Children's Singing Aptitudes Using Music Therapy.« Procedia: Social and Behavioral Sciences 82 (3): 818-823.

Diaz Abrahan, V. M., F. Shifres in N. R. Justel. 2020. »Music Improvisation Modulates Emotional Memory.« Psychology of Music 48 (4): 465-479.

Duh, M., in J. Črčinovič Rozman. 2007. »Apreciacija kot skladnost doživljanja glasbenih in likovnih umetnin."Sodobna pedagogika 58 (3): 92-109.

Fallon, V. T., S. Rubenstein, R. Warfield, H. Ennerfelt, B. Hearn in E. Leaver. 2020. "Stress Reduction From a Musical Intervention. $P$ Psychomusicology: Music, Mind and Brain 30 (1): 20-27.

Fortuna, S., in L. Nijs. 2020. »Children's Representational Strategies Based on Verbal Versus Bodily Interactions with Music: An Intervention-Based Study."Music Education Research 22 (1): 107-127.

Košir, K., in K. Habe. 2013. »Analiza dejavnikov učnega okolja na osnovi hierarhije potreb Abrahama Maslowa.« Revija za elementarno izobraževanje 2-3 (6): 173-191.

Hilliard, R. 2007. »The Effects of Orff-Based Music Therapy and Social Work Groups on Childhood Grief Symptoms and Behaviors. « Journal of Music Therapy 44 (2): 123-138.

Hodges Wood, A. 2008. »Effects of Music Therapy on Preterm Infants in the Ne- 
onatal Care Unit.« Doktorska disertacija, University of Alabama at Birmingham.

Ilie, G., in R. Rehana. 2013. »Effect of Individual Music Listening on Acute-Stress Recovery." Canadian Journal of Music Therapy 19 (1): 23-46.

Jacobsen, S., C. S. McKinney in U. Holck. 2014. »Effects of a Dyadic Music Therapy Intervention on Parent-Child Interaction, Parent Stress, and Parent-Child Relationship in Families with Emotionally Neglected Children: A Randomized Controlled Trial.« Journal of Music Therapy 51 (4): 310-332.

Jeznik, K. 2015. »Od prepoznavanja do pripoznavanja identitete otrok in mladostnikov."Sodobna pedagogika 66 (3): 46-62.

Johnson, R. V. 2001. Vse o nosečnosti in otrokovem prvem letu: najpopolnejši vidik za bodoče starše. Ljubljana: Educy.

Jones, J. D. 2006. "Songs Composed for Use in Music Therapy: A Survey of Original Songwriting Practices in Music Therapy.« Journal of Music Therapy 43 (2): 94-110.

Koelsch, S. 2011. »Toward a Neural Basis of Processing Musical Semantics.« Physics of Life Reviews 8 (2): 89-105.

- 2020. »A Coordinate-Based Meta-Analysis of Music-Evoked Emotions." Neurolmage 223 (2): 1-10.

Kopačin, B. 2014. »Medsebojna povezanost inteligentnosti, glasbenih aktivnosti in družinskega okolja pri devetošolcih." Revija za elementarno izobraževanje 2 (7): 81-96.

Kroflič, R. 2011. »On the Image of the Rich Child, and on Democracy and Experimentation as Preconditions for Good Preschool Education: An Interview with Prof. Peter Moss. «Sodobna pedagogika 62 (4): 155-171.

Marjanovič Umek, L. 2014. "Strukturna kakovost vrtca: učinek na procesno kakovost in dosežke otrok."Sodobna pedagogika 65 (2): 10-22.

Mawby, S. 2015. »Music Education and Music Therapy in Schools for Children with Special Educational Needs: Similarities, Crossovers and Distinctions." Prispevek predstavljen na Ninth Triennial Conference of the European Society for the Cognitive Sciences of Music (ESOM), Manchester, Združeno kraljestvo, 17.-22. avgust.

Oldfield, A. 2006. Interactive Music Therapy: A Positive Approach. London: Jessica Kingsley.

Oldfield, A., in C. Flower 2008. Music Therapy with Children and their Families. London: Jessica Kingsley Publishers.

Orff, G. 1974. Die Orff - Musiktherapie. München: Fische Tashenbuch.

Paladin, M. 2015. »Neverbalna komunikacija v izobraževalnem kontekstu skozi oči učencev.«Pedagoška obzorja 30 (2): 75-90.

Plut Pregelj, L. 2012. Poslušanje. Ljubljana: DZS.

Schwartzberg, E., in M. Silverman. 2014. »Music Therapy Song Repertoire for Children with Autism Spectrum Disorder: A Descriptive Analysis by Treat- 
ment Areas, Song Types and Presentation Styles."Arts in Psychotherapy 7 (41): 240-249.

Simpson, J. 2013. »The Effect of Music Therapy on Social Skills Training in a Preschool Setting.« Doktorska disertacija, Florida State University.

Smith, T., ur. 1994. Družinska zdravstvena enciklopedija. Prev. M. Likar idr. Ljubljana: DZS.

Stern, D. N. 2018. The Interpersonal World of the Infant. New York: Routledge.

Topolovec, U., in M. Scmidt. 2015. „Šolanje osnovnošolcev s posebnimi potrebami.«Pedagoška obzorja 30 (3-4): 3-18.

Ule, M. 2015. »Vloga staršev v izobraževalnih potekih otrok v Sloveniji.« Sodobna pedagogika 66 (132): 30-45.

Wambach, M., in B. Wambach. (1999). Drugačna šola, konvergentna pedagogika v osnovni šoli. Prev. M. Schlamberger Brezar. Ljubljana: DZS.

Waters, H. D. 2015. »Adults and Young Children as Music Co-Researchers: Narratives from a Play-based, Reggio-Emilia-Inspired Preschool.« Doktorska disertacija, Temple University Graduate Board.

Wigram, T. 2000. »Special Feature. A Method of Music Therapy Assessment for the Diagnosis of Autism and Communication Disorders in Children.« Music Therapy Perspectives 18 (1): 13-22.

- 2004. Improvisation: Methods and Techniques for Music Therapy Clinicans, Educators and Students. London: Jessica Kingsley.

World Federation of Music Therapy. B. I. »About WFMT.« B. I. https://wfmt.info/ wfmt-new-home/about-wfmt/.

\section{Music as the Connecting Element of Pre-Schoolers with Their Home Environment}

This paper examines music as a connecting element of pre-schoolers and their home environment. Within the research, music lessons were implemented in three kindergartens in northeast Slovenia over a course of a year. We focused on what form of musical interaction parents establish with their children through the teaching content, to what extent parents are interested in music lessons in kindergartens, how well they know them and how relevant they consider lessons to be. The research included 285 children of both age groups and their parents. The results have shown that children's songs and dance are the most common musical interactions, parents are more likely to establish musical interaction with younger children, and those with higher education are more likely to connect through singing. The findings reflect the important role of music as a connecting element between parents and children with institutions. Parents were interested in music contents being performed and assessed them as important.

Keywords: preschool music, musical activities, music therapy, music improvisation, child-parent music interaction 